\title{
Effect of Ayurvedic Treatment Protocol on Diminishing Ovarian Reserve
}

\author{
Research Article
}

\section{Divya $\mathbf{U}^{*}$, Vijayakumar $\mathbf{N}^{2}$}

1. Assistant professor, Department of PTSR, PNNM Ayurveda Medical College, Shornur, Kerala 2. Former HOD and Professor Department of PTSR, Government Ayurveda College, Trivandrum, Kerala

\begin{abstract}
Diminishing ovarian reserve (DOR) is a condition in which the ovary loses reproductive potential, compromising fertility. Nowadays $10-30 \%$ of female infertility is due to DOR and considered as "expected poor responder" for In vitro fertilisation (IVF). Correlation of DOR can be done with Dathukshaya vandya (depletion or inadequate formation of dhatus) explained in Harithasamhita. The objective of the study was to evaluate the effect of Ayurvedic treatment protocol on Diminishing ovarian reserve. The study protocol includes- ashtachurna for deepana (appetiser), pachana (digestives) and kolakulathadi churna for udwarthana (powder massage). Sukumaragrutha used for snehapana (oral administration of medicated ghee), utharabasthi (intrauterine administration) and rasayana (rejuvenation therapy). Danwantarathaila abhyanga (oleation) and ooshmasweda (sudation) done for 3 days. Sukumaraeranda was used for virechana (therapeutic purgation) and also Yogabasthi (medicated enema). The study design was pre and post interventional study with a sample size of 15 selected as per inclusion and exclusion criteria, conducted at hospital for women and children, Government Ayurveda College, Thiruvananthapuram. Assessment was based on Bologna criteria for DOR. The statistical techniques employed are Wilcoxon's signed rank test and Paired t test. Results showed statistically significant effect on improving Antral follicle count (AFC) (p- 0.01), Estradiol (p0.005 ), conception ( $p-0.014$ ), on regulating amount of bleeding ( $p-0.003)$, menstrual interval correction ( $p-0.001)$ and dyspareunia (p-0.005). But insignificant effect on improving Anti Mullerian Hormone (AMH) (p- 0.469) and regularising $\mathrm{LH} / \mathrm{FSH}$ ratio (p-0.104) was found.
\end{abstract}

Key Words: Dhatukshaya vandhya, AMH, AFC, LH, FSH, Estradiol, Yogavasthi, Snehapana.

\section{Introduction}

Diminishing ovarian reserve (DOR) refers to the reduction of oocyte quantity, quality and reproductive potential (1). As per European Society of Human Reproduction and Embryology (ESHRE) \& Bolognas criteria for DOR at least any of the two of the following should be present i.e. Age $<38$ years, abnormal ovarian reserve test, and poor response to previous stimulated cycle(2). Nowadays $10-30 \%$ of female infertility is due to DOR (3). As per Institute for social and Economic Change (ISEC) survey $14 \%$ of Indian women attains menopause between the ages of 29-34 years (4) Aetiologies are heterogeneous, associated with $\mathrm{X}$ chromosome abnormalities causing ovarian dysgenesis (5). Other factors include autoimmune (auto-reactive lymphocytosis, organ specific autoantibodies), iatrogenic (chemotherapy, ovarian drilling and uterine artery embolization), oxidative stress (ROS-induced DNA damage causes granulosa cell apoptosis, follicular atresia, chromosomal abnormalities) and endocrine disrupting chemicals (e.g.

\section{* Corresponding Author:}

\section{Divya U}

Assitant Professor,

Department of Prasuti Tantra and Sthriroga (PTSR),

PNNM Ayurveda College, Shornur.

Email Id: divyadg7@gmail.com
Polycyclic aromatic hydrocarbons, tobacco (6). Exact mechanism for development of DOR is obscure. It can be due to preliminary decrease/ defective maturation/ recruitment of primordial follicles and accelerated atresia of follicles. Clinical features include vasomotor symptoms such as hot flushes, osteoporotic changes, vaginal dryness, dyspareunia, sleep disturbances and mood swings etc. The long term consequences are infertility, premature ovarian failure, osteoporosis, cardiovascular, neurologic diseases and risk of premature death (7).

Table 1: Assessment factors (8)

\section{Assessment factors Levels (DOR)}

Basal Antimullerian Below $1.5 \mathrm{ng} / \mathrm{dl}$

Hormone (AMH)

Basal Follicle $10-15 \mathrm{IU} / \mathrm{L}$

stimulating hormone

(FSH)

Basal Estradiol $\quad 60-80 \mathrm{pg} / \mathrm{ml}$

Basal Inhibin B $\quad$ Less than $400 \mathrm{pg} / \mathrm{ml}$

Ultra sonography - Antral follicular count (AFC $<10$ both ovaries)

- Ovarian volume, Ovarian artery blood flow 
Dynamic test

- Clomiphene citrate challenge test (CCT), Exogenous FSH ovarian response (EFTORT), Gonadotropin agonist stimulation test (GAST)

In conventional medicine system the treatment options are limited. DOR is considered as "expected poor responder" for In vitro fertilisation (9). Adjuvant therapy with LH, DHEA and growth hormones shows some benefit in oocyte yield but long term treatment may leads to conditions like breast $\mathrm{CA}$, ovarian $\mathrm{CA}$ and fibroid uterus etc (10).

Anapathyathal Vandhyaha is one among vaataja yonivyapath and mentioned as symptom, sign and complication of diseases. It means failure to achieve a child rather than pregnancy as garbha strava (repeated abortions) and mrutvatsa (repeated still births) are also included in types (11). Improper dietetics and mode of life, abnormalities in the sukra (spermatozoa) and asrug (oocyte), diseases of reproductive tract, akalayoga (sexual intercourse during non-ovulatory phase) and balakshaya (reduction of reproductive potential) all are included in the causative factors (12). As per Ayurveda, DOR can be most appropriately correlated with Dathukshaya vandya, explained in Haritha samhita (13). It is due to depletion or inadequate formaton of dhatus which leads to reduction in fertility potential and ultimately anapathyatha.
Vandhya chikithsa in Ayurveda comprises a multifactorial approach rasayana chikitsa followed by shodhana is found to have promising results in management of DOR.

\section{Objective}

To evaluate the effect of Ayurvedic treatment protocol on Diminishing Ovarian Reserve.

\section{Methodology}

Single group, pre and post interventional study with sample size of 15 was conducted in the OPD and IPD of Govt. Ayurveda college Hospital for women and children, Thiruvananthapuram. Inclusion criteria: Females in the age group 20-35 years, diagnosed as per Bologna criteria.

Exclusion criteria: Peri- menopausal women, systemic illness excluding diabetes mellitus and thyroid dysfunction, history of chemotherapy, ovarian drilling and auto immune disease.

Sampling technique: Consecutive selection of subjects satisfying inclusion and exclusion criteria

Primary outcome variables: Basal values of AMH, LH/FSH ratio, AFC, and Estradiol.

Secondary variables: Conception, Amount of menstrual bleeding, Menstrual interval dyspareunia

The statistical techniques: Descriptive statistics, Wilcoxon's signed rank test and Paired t test.

Table 2: Description of study protocol

\begin{tabular}{|c|c|c|}
\hline Day & Treatment Protocol & Medicine \\
\hline $1^{\text {st }-5^{\text {th }}}$ & $\begin{array}{c}\text { Deepana- Pachana } \\
\text { (digestives \& appetisers) }\end{array}$ & $\begin{array}{l}\text { Ashtachurna }(14) \\
\text { Dose- } 15 \text { gm BD orally }\end{array}$ \\
\hline $1^{\text {st }} 5^{\text {th }}$ & Udwarthanam (Powder massage) & Kolakulathadi churna (15) \\
\hline $6^{\text {th }}-12^{\text {th }}$ & $\begin{array}{c}\text { Snehapanam } \\
\text { (Internal administration of medicated } \\
\text { ghee) }\end{array}$ & $\begin{array}{c}\text { Sukumara grutham (16). Progressively increasing dose } 25 \\
\mathrm{ml} \text { to } 175 \mathrm{ml}\end{array}$ \\
\hline $13^{\text {th- }} 15^{\text {th }}$ & $\begin{array}{l}\text { Abhyanga and ooshma sweda. } \\
\text { (Oleation \& sudaton for } 30 \text { minutes ) }\end{array}$ & $\begin{array}{l}\text { Dhanwantharam thailam (17). } \\
\text { Dose- Quantity sufficient. }\end{array}$ \\
\hline $16^{\text {th }}$ & $\begin{array}{l}\text { Mruduvirechanam. (Therapeutic } \\
\text { purgation) }\end{array}$ & $\begin{array}{l}\text { Sukumara erandam. } \\
\text { Dose- } 20 \mathrm{ml} \text { on empty stomach }\end{array}$ \\
\hline \multirow[t]{2}{*}{$17^{\text {th }}$} & Rest & \\
\hline & YOGA BASTHI (Therapeutic enema) & \\
\hline $18^{\text {th }}$ & $\begin{array}{c}\text { Sneha basthi. (Enema with medicated } \\
\text { oil) }\end{array}$ & Dhanwanthara thailam. Dose - $60 \mathrm{ml}$ \\
\hline $19^{\text {th }}$ & Sneha basthi & Dhanwantharam thailam, $-60 \mathrm{ml}$ \\
\hline $20^{\text {th }}$ & $\begin{array}{l}\text { Kashaya basthi. } \\
\text { (Medicated decoction enema) }\end{array}$ & $\begin{array}{c}\text { Sapthasaram kashayam (18), }-480 \mathrm{ml} \text { dhanwantharam } \\
\text { thailam- } 120 \mathrm{ml} \text {, sathapushpa kalkam } 30 \mathrm{gm}, \\
\text { Saindavam } 10 \mathrm{gm} \text { and madhu } 120 \mathrm{ml} .\end{array}$ \\
\hline $21^{\text {st }}$ & Sneha basthi & Dhanwantharam thailam. $60 \mathrm{ml}$ \\
\hline $22^{\text {nd }}$ & Kashaya basthi & $\begin{array}{l}\text { Sapthasaram kashayam } 480 \mathrm{ml} \text {, Dhanwantharam thailam } \\
120 \mathrm{ml} . \\
\text { Sathapushpa kalkam } 30 \mathrm{gm}, \text { Saindavam 10gm, Madhu }-120 \\
\mathrm{ml}\end{array}$ \\
\hline
\end{tabular}




\begin{tabular}{|c|c|c|}
\hline $23^{\text {rd }}$ & Sneha basthi & Dhanwantharam thailam. $-60 \mathrm{ml}$ \\
\hline $24^{\text {th }}$ & Kashaya basthi & $\begin{array}{c}\text { Sapthasara kashayam-480 } \mathrm{ml} \text { Dhanwantharam thailam- } 120 \\
\mathrm{ml}\end{array}$ \\
\hline & & $\begin{array}{c}\text { Sathapushpa kalkam, - } 30 \mathrm{gm} \\
\text { Saindavam } 10 \mathrm{gm} \text { and Madhu-120ml }\end{array}$ \\
\hline $25^{\text {th }}$ & Sneha basthi & Dhanwantharam thailam.60 ml \\
\hline $6^{\text {th-2 }} 8^{\text {th }}$ & $\begin{array}{c}\text { Uthara basthi. (Intrauterine instillation of } \\
\text { medication) }\end{array}$ & Sukumaram grutham- $30 \mathrm{ml}$ \\
\hline 60days & Rasayana (Rejuvenation therapy) & Sukumara grutham \\
\hline
\end{tabular}

The study was commenced after the $4^{\text {th }}$ day of menstrual cycle and sodhana suspended during bleeding phase.

\section{Result}

Analysis showed among the study population $80 \%$ were vata-paithika prakruthi (body constitution) and $20 \%$ vata-kapha prakruthi. Regarding psychological statuses $46.67 \%$ anxious and $26.67 \%$ were depressed. Majority of patient had relevant family history of premature menopause (33.33\%). In the population $(80 \%)$ were passive smokers. Primary infertility was reason for encounter among all the subjects. All the subjects had history of negative results for stimulation strategy. Detailed clinical picture are shown in the diagram 1, 2.

Diagram: 1 Data regarding treatment history

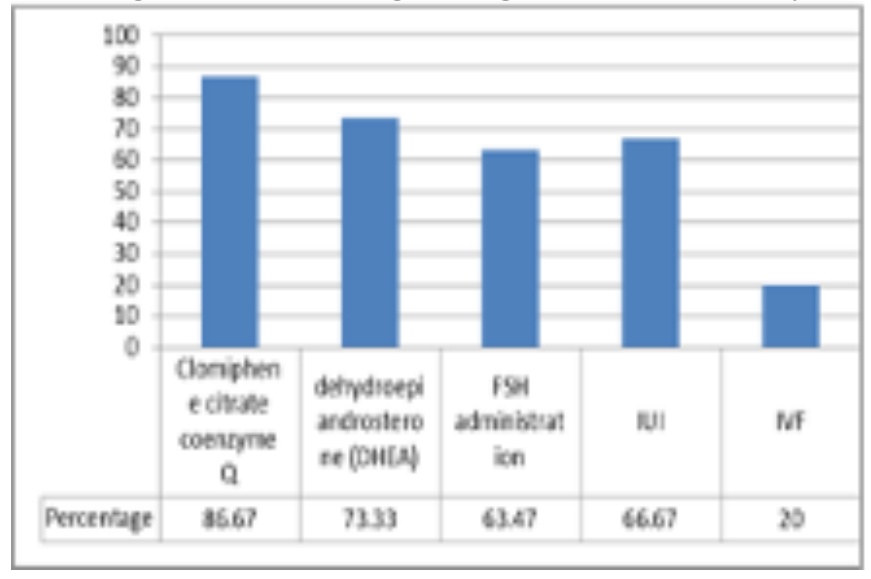

Diagram: 2 Data regarding clinical picture

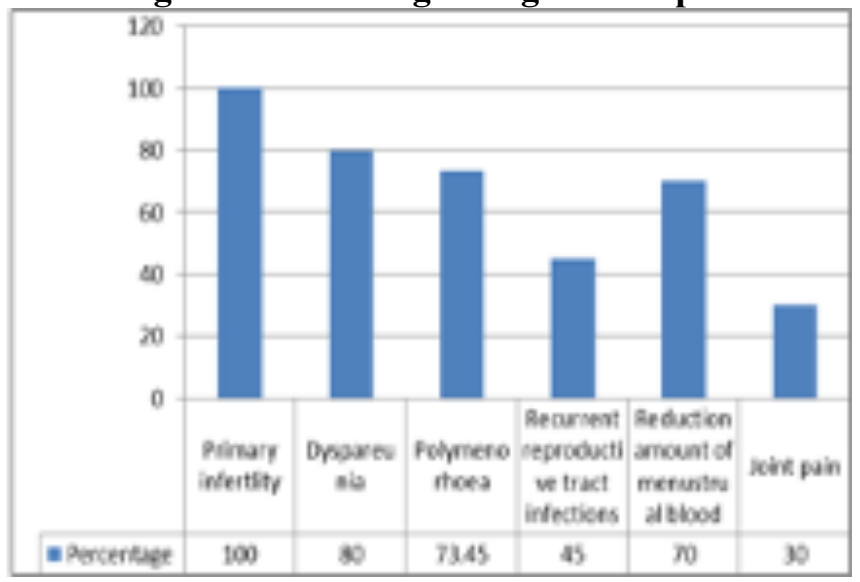

Table 3: Data related to effectiveness of treatment on AMH \&AFC

\begin{tabular}{|c|c|c|c|c|c|}
\hline No & $\begin{array}{l}\text { AMH } \\
\text { BT (pmol/L) }\end{array}$ & $\begin{array}{l}\text { AMH } \\
\text { AT (pmol/L) }\end{array}$ & $\begin{array}{l}\text { AFC } \\
\text { BT }\end{array}$ & $\begin{array}{l}\text { AFC } \\
\text { AT( } 3 \text { months) }\end{array}$ & $\begin{array}{l}\text { AFC } \\
\text { AF (6 months) }\end{array}$ \\
\hline 1 & 3.99 & 4 & 5 & 8 & 6 \\
\hline 2 & 8.72 & 8.1 & 5 & 10 & 9 \\
\hline 3 & 3.57 & 4.29 & 2 & 10 & Conceived \\
\hline 4 & 11.74 & 7.46 & 6 & 12 & 7 \\
\hline 5 & 10.26 & 20.2 & 6 & 8 & Conceived \\
\hline 6 & 15 & 34.28 & 5 & 7 & 6 \\
\hline 7 & 7.46 & Conceived & 2 & Conceived & Conceived \\
\hline 8 & 1.36 & Conceived & 4 & Conceived & Conceived \\
\hline 9 & 8.31 & 6.9 & 2 & 14 & 10 \\
\hline 10 & 7.31 & 4.3 & 6 & 16 & 8 \\
\hline 11 & 2.71 & 3.5 & 3 & 15 & 12 \\
\hline 12 & 12.27 & 12.95 & 4 & 4 & 4 \\
\hline 13 & 12.74 & 9.006 & 6 & 11 & 12 \\
\hline 14 & 12.12 & 11.9 & 3 & 11 & 10 \\
\hline 15 & 5.53 & 4.2 & 5 & 8 & 6 \\
\hline
\end{tabular}

Two patients conceived during treatment and 4 patients conceived after treatment. A patient who was suggested IVF with donor oocyte (AMH level $1.36 \mathrm{pmol}$ i.e. very low fertility rate) conceived after treatment. Data on pre-test and post-test were collected for parameters for rest of the subjects $(n=13)$. Data was assessed with paired t-test and Wilcoxon's signed rank test. 
Diagram no.3: Data related to AFC

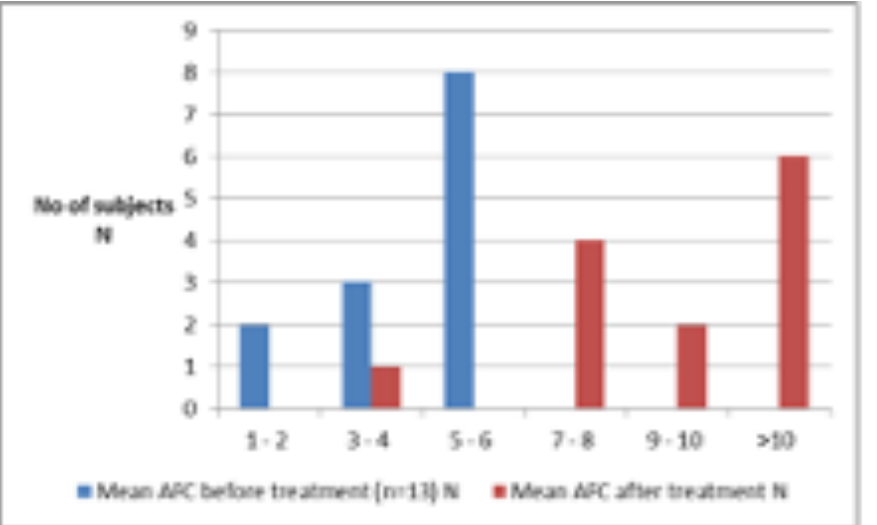

Diagram no.4: Data related to AMH

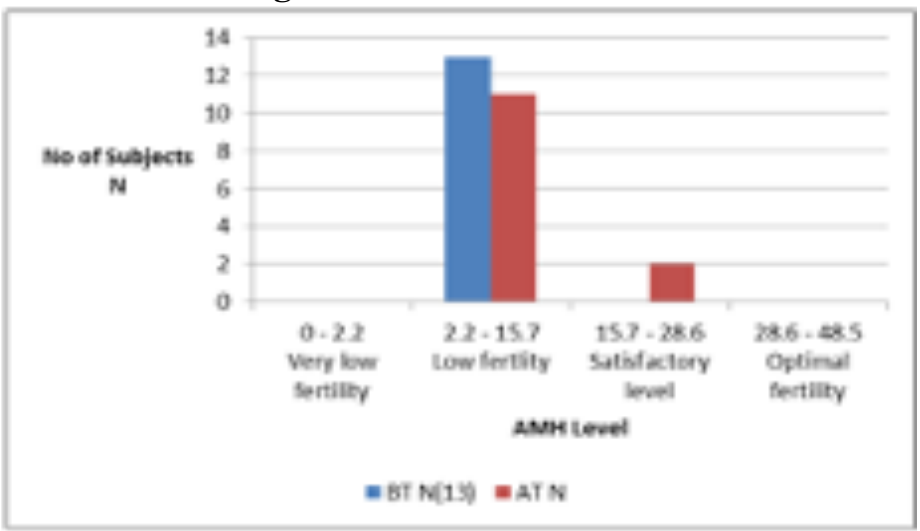

BT - Before treatment, AT - After treatment, AF - After follow up

Diagram no.5: Data related to LH/FSH

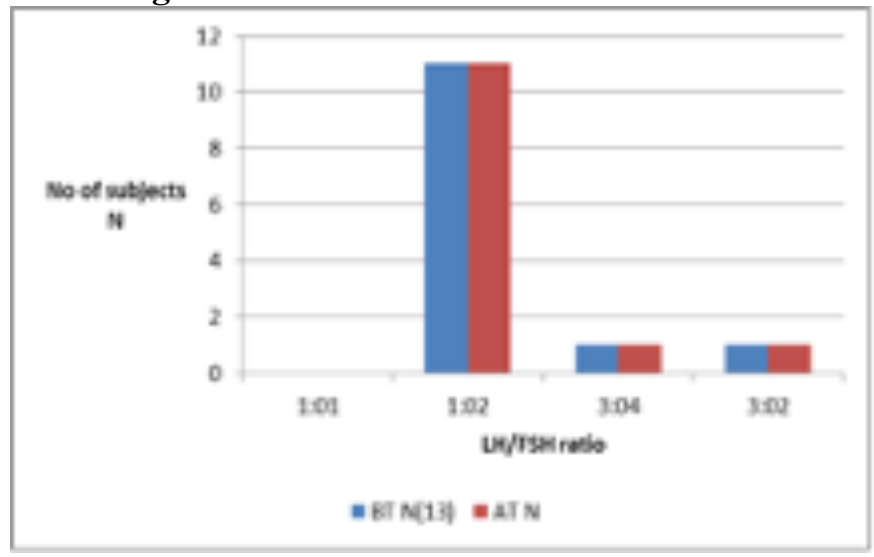

Diagram no.7: Data related to Conception

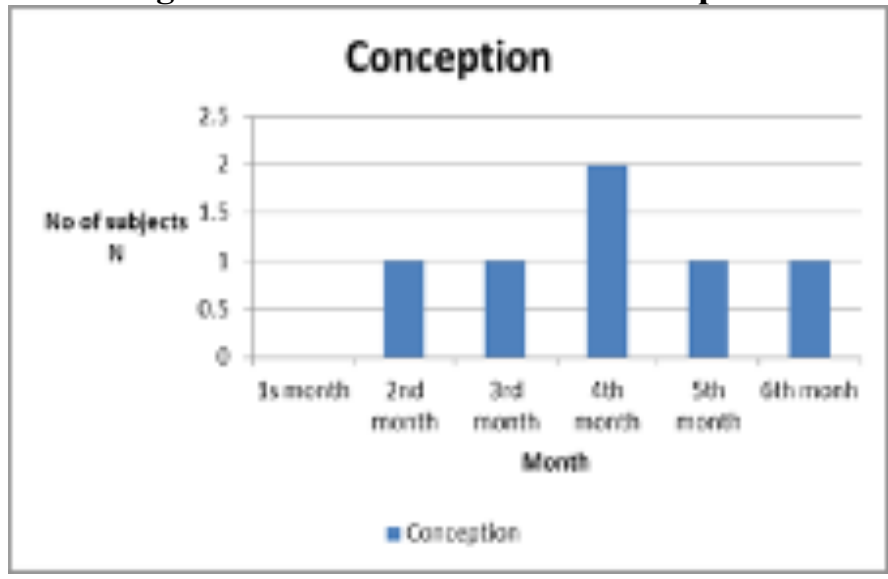

Diagram no.9: Data related to menstrual interval

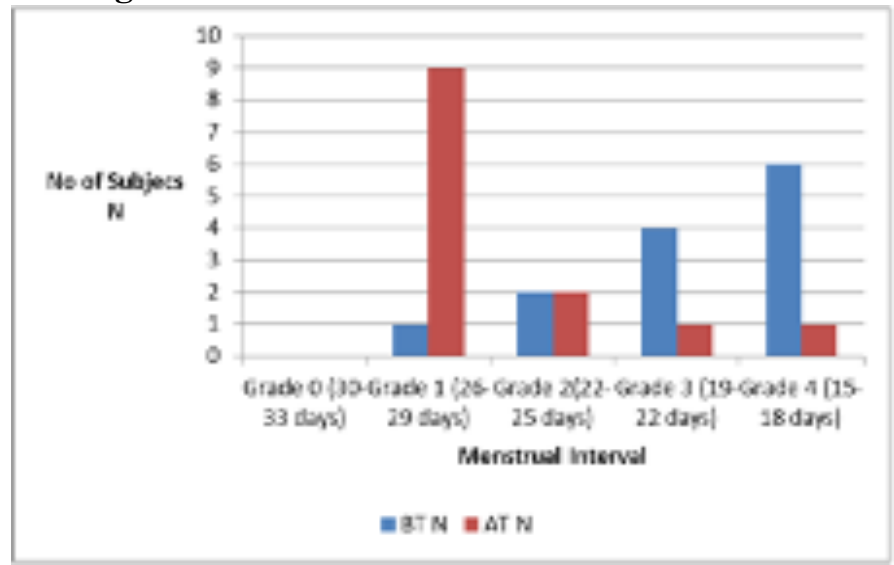

\section{Diagram no.6: Data related to Esrtadiol}

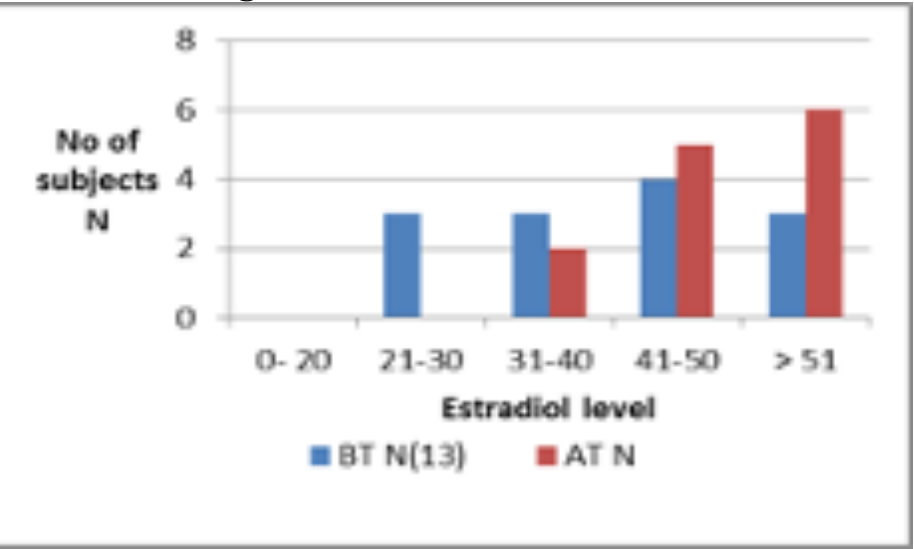

Diagram no.8: Data related to bleeding

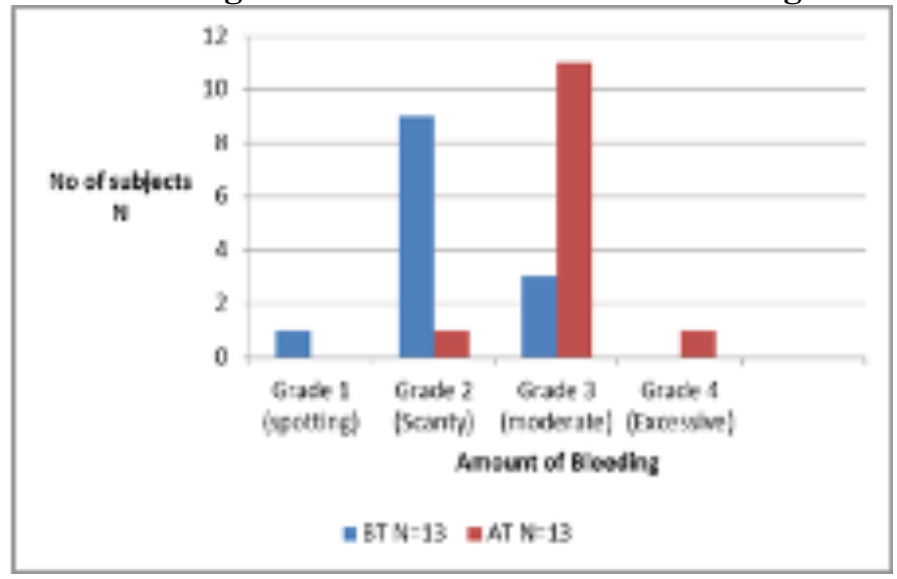

\section{Diagram no.10: Data related to Dyspareunia}

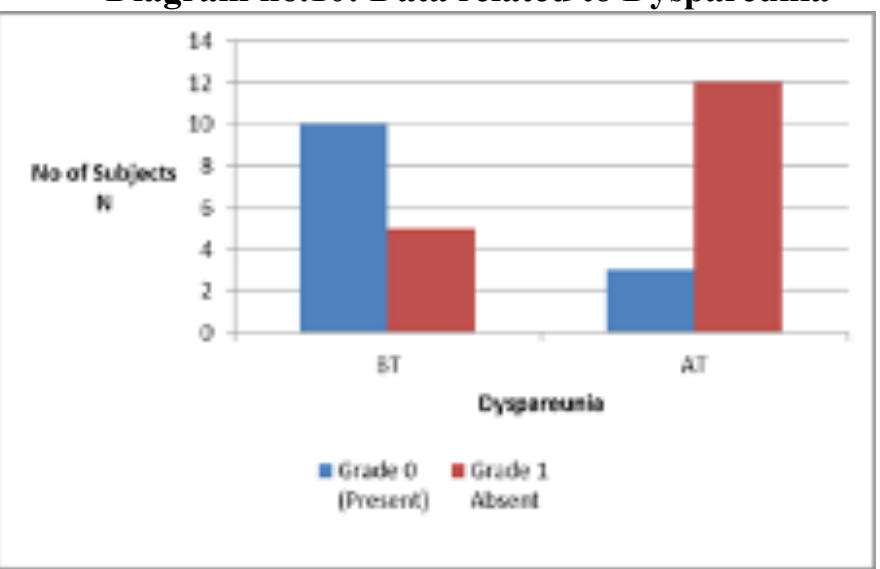


Table 4: Paired t-test results

\begin{tabular}{|c|c|c|c|}
\hline Variable & Test & Z & $\mathrm{P}$ \\
\hline Conception & AF-BT & -2.249 & 0.0414 \\
\hline $\begin{array}{l}\text { Amount of } \\
\text { bleeding }\end{array}$ & AT-BT & -3 & 0.003 \\
\hline $\begin{array}{l}\text { Menustral } \\
\text { interval }\end{array}$ & AT-BT & -3.225 & 0.001 \\
\hline Dyspareunia & AT-BT & -2.828 & 0.005 \\
\hline
\end{tabular}

Table 5: Wilcoxon's signed rank test results

\begin{tabular}{c|c|c|c|}
\hline Variable & Test & $\mathrm{Z}$ & $\mathrm{P}$ \\
\hline Conception & AF-BT & -2.249 & 0.0414 \\
\hline $\begin{array}{c}\text { Amount of } \\
\text { bleeding }\end{array}$ & AT-BT & -3 & 0.003 \\
$\begin{array}{c}\text { Menustral } \\
\text { Interval }\end{array}$ & AT-BT & -3.225 & 0.001 \\
\hline Dyspareunia & AT-BT & -2.828 & 0.005
\end{tabular}

Results showed statistically significant values obtained on conception (p-0.014, six patients conceived among 15 subjects), regulating amount of bleeding ( $\mathrm{p}$ $0.003)$, menstrual interval correction (p-0.001), minimising dyspareunia ( $\mathrm{p}-0.005)$, and improving AFC (p-value $<0.01$ ). After treatment no considerable change in ratio LH/FSH ratio (p-value 0.104) was found. Before treatment all the patients had normal level of mean ovarian volume $(>15 \mathrm{cc})$ Majority were under the group7-9 cc and after treatment no difference was observed. As the paired t test showed a p-value 0.005 , it can be concluded that there is statistically significant increase of S. Estradiol before treatment and after treatment. After treatment considerable increase in value AMH was not found. As the paired $t$ test showed a p-value 0.469 (i.e., p >0.05), it can be concluded that there is statistically insignificant difference between AMH before treatment and after treatment (details are given in table 4,5).

\section{Discussion}

From the broad references described in the classics the condition like arthava kshaya (19) due to apakwa rasadhathu formation as a consequence of vishamagni (20) can be considered as reduction in reproductive potential due to oxidative stress. Symptoms like daaha, santhaapa (hot flushes) rajo athipravruthi (shortening of menstrual cycle) are seen in early stages of DOR. When untreated and apathya sevana (unwholesome habits) is continued leads to vaata vrudhi, pitha-kapha kashaya causing rasadi dhathu kshaya i.e. roopaavastha (disease manifestation). Vandhyathwa (infertility) due to beeja dhushi as seen in shanda, vartha (21) etc. can be correlated with premature ovarian failure in X -linked chromosomal abnormities. In ovarian surgery arthavavaha srotho vighatha (22) can be seen leading to arthava nasha (destruction of follicular reserve), vandhyathwam and maithuna asahishnutha (dyspareunia) gradually leads to uthorathara dhathukshaya (impaired formation of further dhatus) where upadrava lakshanaas (complications) like akala jara and bala kshaya (e.g. symptoms of early aging.).

As per Ayurveda vandhyathwa is managed with sodhanachikithsa (body purification) and utharavasthi so as to get a healthy progeny devoid of beeja dhushti (abnormalities of germ cells). Ashta churna is used for deepana is kaphavatahara in action. As per Ashtanga hrudaya dwividha upakramaneeya adhyaya, rookshana should be done prior to snehana chikithsa. (23) Thus for rookshana udwarthana is carried out along with deepana pachana. Kolakulathadi churna is vatakaphahara in nature. It removes the samaavastha and detaches the vitiated dhoshas adhered to srothas. Snehana (abhyanthara and bahyasneha) done after deepana- pachana. Saptha dhathus are formed from the essence of sneha thus proper snehana does jaataragni vrudhi (enhances digestive power), koshta visudhi (Purifies channels), formation of prathyagra dhathu (enhances quality of dhatus), bala (immunity) and varna (complexion) also increases life span. Sukumara ghritha is used for snehapana, as per indication it is pushtidham (improves vitality) also enhances kanthi lavanya (complexion), yonishoolahara (reduces painful conditions of reproductive tract) and also for men who are debilitated with excess sexual intercourse (Nrinaam sthreevrinttha barthrunam alakshmi kali nashanam). For abhyanga dhanwantharam thailam which is tridhoshahara is selected. According to indication it can be used in diseases of vata and diseases of female reproductive tract (sarvavata vikarajith, kshata ksheeneshu poojitham yoniroga kshayapaham).

Sodhana (vamana, virechana) done after purvakarma expels the vitiated dhoshas from koshta. As per kasyapa virechana is the main treatment for improving beeja karmukatha (increased fertility potential of germ cells) (24). It pacifies the vitiated kapha and vatadosha and removes vitiated excessive Pitta and thus does raktashodhana (blood purification). In the present study mrudhu virechana with sukumara eranda (dose $20 \mathrm{ml}$ ) was opted as it is a dhatuksheena avastha (debilitated condition). As it was mudu shodhana one day samsarjana karma (regimen after sodhana) was done. Vasthi karma is indicated in alparaja and anarthava (conditions associated with male and female infertility) especially yapanna vasthi is indicated in infertility.(25) Here madhuthailika vasthi is chosen is having bhrimhana in nature and the drugs are dhanwnatharam thailam as snehadravya, sapthasaram kashayam which is kapha vatahara in nature and indicated in diseases of yoni (reproductive organs). Utharavasti should be administered after sodhana. It facilitates direct drug administration into uterus and accelerates formation of avyapanna garbhava samagri (factors essential conception). As per Charaka substance which maintains health by producing the best quality of rasa, rakta dhatu etc dhatus are called as rasayana. It is vayasthapana, ayushkara, medhakara and urjaskara (delays aging process, improves memory power and vitality). (26) Thus the medicines included in treatment protocol will enhance production of avyapanna garbha sambhava samagri and hence the preservation of fertility status can be restored. 
Role of vata in the manifestation of disease was substantiated by prakruthi assessment i.e vata-paithika, vata-kapha prakruthi of subjects. Strong association of passive smoking was found. Tobacco is an endocrine disrupting chemicals (EDCs) causing alteration of ovarian function. EDCs can be correlated with dhushivisha (substances in small doses are asymptomatic but cumulative effect are hazardous). When accumulated over rasadi dhathus causes pradhoshaja rogas (diseases due vitiation of dhathu) like vandyathwa (27). Primary infertility, shortening of menstrual cycle, scanty menstruation, hot flushes and dyspareunia are seen in all cases. The study was significant at $1 \%$ level on conception $(46.15 \%)$, normalizing menstrual interval, increasing amount of bleeding, AFC, and dyspareunia though it was not effective in increasing in $\mathrm{AMH}$, and regularising $\mathrm{FSH} /$ LH ratio. All the subjects had treatment history unresponsive to stimulation strategy. Conception was occurred in a patient suggested IVF with donor oocyte having $\mathrm{AMH}$ level 0.01 (very low fertility rate), $\mathrm{AFC}=0$ (value BT) got conceived and also in patients who had AMH level below satisfactory level. This indicates $\mathrm{AMH}$ is not a determining factor and there are other unknown factors which favors fertility potential of oocyte. Increasing basal values of antral follicles, esteradiol indicates appropriate oogenesis. Adopted protocol improves the quality of ovum thus restoration of fertility potential, along with reduction in the magnitude of associated complaints. Cost effectiveness, enhanced safety and efficacy will benefit for the society and will project Ayurveda into the main stream treatment.

\section{Conclusion}

Study shows significant effect on markers of ovarian reserve such as antral follicle count and estradiol and also in the clinical parameters such as conception, regulating menstrual bleeding pattern, interval and dyspareunia. But significant effect on Anti Mullerian Hormone and regularising LH/FSH ratio was not found. For precise data researches on larger samples have to be conducted. Pregnancy is the conclusive evidence for restoration fertility potential. Even though conspicuous change in the markers of ovarian reserve was established it's evident that the study is effective in managing diminishing ovarian reserve.

\section{References}

1. Artini PG, Ruggiero M, Uccelli A, Obino ME, Cela V (2013) Fertility Management of Patients with Reduced Ovarian Reserve. Reprod Sys Sexual Disorders S5:006. doi:10.4172/2161-038X.S5-006

2. Testing and interpreting measures of ovarian reserve: Fertil Steril 2015; 103: e9-e17

3. J Clin Invest. 2007; 117(12):3971-3978. https:// doi.org/10.1172/JCI28493.

4. www.isec.ac.in

5. Rasool S, Shah D. Fertility with early reduction of ovarian reserve: the last straw that breaks the
Camel's back. Fertility Research and Practice. 2017;3:15. doi:10.1186/s40738-017-0041-1.

6. Mandeep kaur,Mala Arora. Diminishing ovarian reserve, causes, assessment and management. IJIFM.2013-May-25, volume (No. 2) 45-54 page no.

7. Pratap Kumar, Narendra Malhotra. Jeffcoate's Principles of Gynaecology. 7th ed. New Delhi: Jaypee Brother Medical Publishers (P) Ltd; 2008.

8. Schorge, Schaffer, Halvorson, Hoffman, Bradshaw, Cunningham. Williams Gynaecology, China Translation and Printing Ltd; 2008. 371, 456, 457, 369, 391, 378.

9. Greene AD, Patounakis G, Segars JH. Genetic associations with diminished ovarian reserve: a systematic review of the literature. J Assist Reprod Genet. 2014;31:935-46

10. https://www.centerforhumanreprod.com.

11. Pandith.Hariprasad tripadi. Haritha samhitha. $4^{\text {th }}$ ed. Varanasi: Chowkhamba Krishnadas Academy: 2015 445-448 page.

12. Premvati Tewari. Ayurvediya Prasutitantra Evam Streeroga Part 2. 2nd ed. Varanasi: ChaukhambaOrientalia; 1999. Page no 356

13. Pandith.Hariprasad tripadi. Haritha samhitha. $4^{\text {th }}$ ed. Varanasi: Chowkhamba Krishnadas Academy: 2015 445-448 page.

14. Aravattzhikathu K V Krishnanvaidyan, Aanekaleelil S Gopalapilla. Sahasra Yogam Sujanapriya Commentary. 27th ed. Aalapuzha: Vidhyarambham publishers; 2007, Page no 81

15. Aravattzhikathu K V Krishnanvaidyan, Aanekaleelil S Gopalapilla. Sahasra Yogam Sujanapriya Commentary. 27th ed. Aalapuzha: Vidhyarambham publishers; 2007, Page no 154

16. Aravattzhikathu K V Krishnanvaidyan, Aanekaleelil S Gopalapilla. Sahasrayogam Sujanapriya Commentary. 27th ed. Aalapuzha: Vidhyarambham publishers; 2007, Page no 454

17. Aravattzhikathu K V Krishnanvaidyan, Aanekaleelil S Gopalapilla. Sahasra Yogam Sujanapriya Commentary. 27th ed. Aalapuzha: Vidhyarambham publishers; 2007, Page no 235

18. Aravattzhikathu K V Krishnanvaidyan, Aanekaleelil S Gopalapilla. Sahasra Yogam Sujanapriya commentary. 27th ed. Aalapuzha: Vidhyarambham publishers; 2007, Page no 332

19. Sreekantha Murthy KR. Susrutha Samhitha. Vol.3. Revised ed. Varanasi: Chowkhamba Orientalia: 2015. 567 page no. 268

20. Yadavji Trikamji Acharya. CharakaSamhitha by Agnivesha, Revised by Caraka and Dridhabala with "Ayurveda deepika"commentary of Cakrapanidatta. Varanasi: Chaukhamba Krishnadas Academy; Samskarana 2006. Page no 855

21. Sreekumar .T. MD(Ay) PhD. Vagbhata's Astanga Hridaya Sutrasthana-1,English Translation and Commentary. 1st ed. Thrissur: Publication Department Harisree Hospital; 2011, page no564

22. Chunekar K.C, G.S.Pandey. Bhavaprakasa nighantu. 10 $10^{\text {the }}$. Varanasi: Chaukhamba Bharati Academy; 1995 page 654 
23. Sreekumar.T MD(Ay) PhD. Vagbhata's Astanga Hridaya Sutrasthana-1,English Translation and Commentary. 1st ed. Thrissur: Publication Department Harisree Hospital; 2011, page no

24. Usha.V.N.K A Text Book of GynaecologyStreerogaVijnan. 1st ed. Delhi: Chaukhamba Sanskrit Pratishthan; 2010 Volume 2, Page no245

25. Yadavji Trikamji Acharya. CharakaSamhitha by Agnivesha, Revised by Caraka and Dridhabala with "Ayurveda deepika"commentary of Cakrapanidatta.
Varanasi: Chaukhamba Krishnadas Academy; Samskarana 2006.Page no467

26. 26. Yadavji Trikamji Acharya. CharakaSamhitha by Agnivesha, Revised by Caraka and Dridhabala with "Ayurveda deepika"commentary of Cakrapanidatta. Varanasi: Chaukhamba Krishnadas Academy; Samskarana 2006. Page no 675.

27. Jyotir Mitra, Ashtanga Sangraha: Chaukhamba Krishnadas Academy; 2002 Page no 152. 